\title{
Food Prices Volatility in Rwanda: A VAR Model
}

\author{
HABYARIMANA Jean Baptiste ${ }^{1, *}$, MUNYEMANA Emmanuel ${ }^{2}$, IMPETA Fred Bashir ${ }^{3}$ \\ ${ }^{1}$ Statistics Service, Ministry of Agricultural \& Animal Resources, Kigali, Rwanda \\ ${ }^{2}$ Research \& Statistics, Ministry of Justice, Kigali, Rwanda \\ ${ }^{3}$ MSc in Economics Scholar, University of Rwanda, Kigali, Rwanda \\ *Corresponding author: kradrimn@gmail.com
}

Received August 20, 2014; Revised December 05, 2014; Accepted December 23, 2014

\begin{abstract}
Market is the main arbiter of how the available food is distributed both within and between countries. Food price volatility informs consumers and price analysts on the availability of food in the region. Food price surges reduce purchasing power of households that are weekly linked to markets and remain obstacle in the way to feed the poor adequately. Thus, Food price surges lead poor people to limit their food consumption and shift to even less-balanced diets, with harmful effects on health in the short and long run. Applying a Vector Autoregressive Model that combines monthly price information on Sorghum, Maize, Rice, Wheat, Irish Potato, and Beans from January, 2007 to December, 2013, this paper tries to forecast food prices volatility in Rwanda and to find out which food commodities' price volatility granger cause price volatility in the other food commodities. In the light of the government of Rwanda efforts aimed to ensure food security to its population, food price volatility could capture the attention of the government of Rwanda. Therefore, food price policies should be oriented to the stabilization of price of food commodities which price volatility granger cause price volatility in the other food commodities.
\end{abstract}

Keywords: food prices volatility, granger causality, and food prices impulse responses

Cite This Article: HABYARIMANA Jean Baptiste, MUNYEMANA Emmanuel, and IMPETA Fred Bashir, "Food Prices Volatility in Rwanda: A VAR Model.” World Journal of Agricultural Research, vol. 2, no. 6 (2014): 296-302. doi: 10.12691/wjar-2-6-9.

\section{Introduction}

Rwanda is a small country (26,338 square $\mathrm{km})$ with high population density "more than 416 people/sq km" [15]. From a tragically low starting point, Rwanda has accomplished a lot in the last decade. Progress with implementing the country's first Economic Development and Poverty Reduction Strategy (EDPRS) has been quite impressive. It has exceeded its poverty reduction targets by reducing poverty from about $56.7 \%$ of the population in $2005 / 6$ to $44.9 \%$ in $2010 / 11$, while extreme poverty has reduced from $35.8 \%$ to $24.1 \%$ [14].

It is therefore, on its way towards poverty reduction and food security that the development of agriculture sector was found to be the major factor to accelerate economic growth of the country. The literature shows that for the last two decades, agriculture system in Rwanda has been improved and the majority of households in Rwanda continue to be employed in agriculture sector (80\%). Nonetheless, food security analysis shows that the market remains the main source of food consumed in households [13]. Beside this, the literature shows that from February, 2009 to February, 2013, Consumer Price Index (PPI) of Food and non-alcoholic beverages and Transport showed an upward trend [14]. This situation shows that households have experienced considerable food price variability led to a great deal of concern because high food prices may have devastating effects in the Rural and Urban areas of Rwanda in terms of market access and food security. As crop yield and prices of agriculture commodities are of considerable interest to food availability, accessibility and sustainability in the country, the main problematic issue however, remains to be the development of an econometric model to forecast food price volatility and identify the causal relationship that exist between food commodities and food price volatility, and link them with demand and supply factors that influence food price volatility.

Food price volatility poses fundamental challenges and opportunities to economists who formulate commodity models to generate information useful to food market agents. Research institutions (Public or Private) working in commodity modeling research could be very instrumental in providing accurate and timely market information for various market participants. Various questions arise regarding the reliability of food market information generated from existing econometric analysis. For example the increase of cereal prices occurred from 2006 to 2013 when compared to the price of cereals from 1998 to 2005 were not instrumentally forecasted accurately with the existing econometric models. This rose from the fact that factors contributing to food price volatility were not deeply examined and not accurately forecasted. Crop yields did not increase at significant rate to cope with the incremental population growth occurred between 2002 and 2012 [15]. Agro-meteorological data show that rainfall variations affected agricultural production [13]. From 1998 to 2013 different parts of the country were hit by rainfall deficit in one way or another (the average amount of rains received are less than the 
long term mean average of rains received) . From 2000 to 2013 exchange rate (Rwanda Francs Vs vehicle currencies like USD and EURO) was significantly deteriorated. In 1998, 2003, 2009, and 2013 1USD was approximately equivalent to 309RWF, 538RWF, 568RWF, and 647RWF respectively (NBR, 1998 - 2013). This situation affected prices of food commodities and agriculture inputs imported. From 2008 to 2013 domestic fuel price increased considerably compared to the significant decrease in fuel price happened at word market (index mundi, 1998 - 2013).

Given the link that exists between food security and food price volatility and the importance of econometric models to analyze causality in food price volatility, the reviewed works show that literature examining food price volatility in Rwanda is scarce. From 2007, there exists a well designed price database. Monthly food prices are recorded and some descriptive statistics are produced mainly in monthly Information Bulletin on Crops produced by the Ministry of Agriculture and Animal Resources (MINAGRI). Also World Food Programme (WFP) uses to produce price trends on monthly basis. A part from this analysis, the National Institute of Statistics of Rwanda (NISR) produces monthly Consumer Price Index (CPI) and Producer Price Index (PPI). However food price analyses typically done in Rwanda show trends of food prices over time, and almost all the existing studies use exclusively descriptive statistics (average prices, monthly percentage changes) and few of them use uni-variate analysis such moving average model (showing trend movement on increase and decrease of food prices). Descriptive statistics and moving average models used, however, have several limitations.

As limitations, such analyses provide little information on specific sources of food price variability and are weak to investigate shocks and their different properties to explain how shocks may differ in their persistence and degree of predictability. The channels through which different shocks reverberate might contain useful information essential to answer questions such as, does price variability in one food commodity affect changes in price in the other food commodity? What is the relative importance of each effect? Addressing such questions requires the use of VAR models. Variance decomposition could also provide useful information about the impact of different shocks on food price variability. This cannot be accomplished with descriptive and/or moving average analyses but with VAR model. In many decision models, the main target is to explain the sources of food price variability and to provide policy implications of finding these sources. Looking into different descriptive and univariate analyses used as main techniques to analysis food prices in Rwanda, we found that there are weak to provide such information and allow providing reliable policy implications of finding the causes of food price volatility.

This paper uses six agriculture commodities (Sorghum, Maize, Rice, Wheat, Beans, and Irish Potato), to conclude from the time series analysis on which variables that can help to explain food price volatility in the last seven years. However this paper aims at forecasting food prices volatility in Rwanda and to find out which food commodities' price volatility granger cause price volatility in the other food commodities.

\section{Methodology and Data Description}

The main purpose of this paper is to explore the long and short run relationship between food prices volatility and forecast food prices volatility in Rwanda using Vector Autoregressive (VAR) Model for Multivariate Time Series. For the selected agriculture commodities (Sorghum, Maize, Rice, Wheat, Irish Potato, and Beans) a VAR model was set up for those six series. To evaluate the model's forecasting accuracy, we used RMSE and RSquare. To determine whether the trend of analyzed food prices is deterministic or stochastic, this paper also explores a test for non stationary (unit root) of time series.

This paper uses Log Transformation and perform unit root test for stationary using ADF. After testing unit root for stationary in logged data and that we were unable to reject unit root, we treated our data for I(1). Therefore, first difference is used to render time series stationary. The ADF is applied by using lag-length that minimize criterion information [5], then the Dickey and Fuller (1979) critical values are used to reject or accept $\mathrm{H}_{0}$ according to the property; if the absolute value of $t$ _statistic is greater than the critical value, then $\mathrm{H}_{0}$ is rejected $\left(\mathrm{H}_{0}\right.$ series $\mathrm{Y}_{\mathrm{t}}$ has a unit root). In what, follows the use of Vector Autoregressive (VAR) Model to perform Grange Causality Test, forecast food price volatility and derive Impulse Response functions.

Granger causality test is considered as a useful technique for determining whether one time series is good for forecasting the other. Granger causality test is used to see how much of a current series $\mathrm{Y}$ can be explained by the past values of $\mathrm{Y}$ and to know whether adding lagged values of another series $\mathrm{X}$ can improve the explanation of the variance of Y or not. Also Granger non-causality is a necessary condition for strong exogeneity [5]. The concept of granger causality test is explored when the coefficients of the lagged of the other variables is not zero. If there are two series Yt \& Xt, then it is said that Xt doesn't granger cause $\mathrm{Yt}$ if all lagged coefficients for $\mathrm{Xt}$ are zero, that is:

$$
\begin{aligned}
& \mathrm{Y}_{\mathrm{t}}=\alpha_{0}+\alpha_{1} \mathrm{Y}_{\mathrm{t}-1}+\ldots+\alpha_{\mathrm{p}} \mathrm{Y}_{\mathrm{t}-\mathrm{p}} \\
& +\beta_{1} \mathrm{X}_{\mathrm{t}-1}+\ldots+\beta_{\mathrm{p}} \mathrm{X}_{-\mathrm{p}}+\varepsilon_{\mathrm{t}}
\end{aligned}
$$

Then $\beta_{1}=\beta_{2}=\ldots=\beta_{\mathrm{p}}=0$, that is lagged of $\mathrm{X}_{\mathrm{t}}$ has no effect on $\mathrm{Y}_{\mathrm{t}}$.

\subsection{Description of Data}

In this paper we use eSOKO data set. eSOKO data set is a web based data set for agricultural commodities prices hosted by the Ministry of Agriculture and Animal Resources Government of Rwanda. The eSOKO data set covers prices data on 68 commodities from 67 markets randomly selected around the country by Urban, SemiUrban and Rural areas and Prices are recorded in Rwandan Francs per Kg (RWF/Kg). For the purpose of analysis we use monthly average prices for each selected commodity. This paper considers food price information collected in 84 months that cover the period between January 2007 and December 2013. eSOKO data sets were available in Excel format but they were merged and analyzed using STATA. From the data sets we decided to use Sorghum, Maize, Rice, Wheat, Irish Potato, and Beans food prices information. 


\section{Empirical Strategy and Results Discussion}

The range of food prices and the difference between minimum and maximum prices and the mean prices of six selected food commodities over the period of January 2007 - December 2013, show that there had been price volatility in selected commodities. The Mean Std Errors and Std. Deviations show that price of Maize and Irish potato per $\mathrm{Kg}$ were slightly stable than that of other commodities whiles the price of Rice and Sorghum were more instable than that of other commodities. Looking at the Skewness, this paper uses logarithmic transformations as a convenient means of transforming skewed variable into one that is more approximately normal.

Table 1. Description of data sets

\begin{tabular}{|c|c|c|c|c|c|c|c|c|}
\hline Commodities & Range & Minimum & Maximum & Mean & Mean Std. Er. & Std. Dev. & Variance & Skewness \\
\hline Sorghum & 240 & 148 & 388 & 245.20 & 6.631 & 60.778 & 3694.043 & 0.699 \\
\hline Maize & 177 & 146 & 323 & 230.07 & 4.131 & 37.857 & 1433.151 & 0.142 \\
\hline Rice & 311 & 450 & 761 & 616.24 & 9.753 & 89.387 & 7989.991 & -0.398 \\
\hline Wheat & 212 & 253 & 465 & 363.02 & 4.703 & 43.100 & 1857.614 & -0.235 \\
\hline Irishpotato & 165 & 92 & 257 & 145.78 & 4.274 & 39.172 & 1534.411 & 0.963 \\
\hline Beans & 334 & 199 & 533 & 311.23 & 7.172 & 65.733 & 4320.996 & 1.072 \\
\hline
\end{tabular}

The results of testing unit root in raw data shows that at 95\% Confidence level, test statistics for all series "Sorghum, Maize, Rice, Wheat, Irish Potato, and Beans" are not statistically significant and this tells us that there is unit root in all series. The results testing unit root in logged data show that all five series have unit root at 95\%

confidence level. This paper uses first difference of logged data for all series to rend them stationary and test if all series satisfy stability condition. Test of unit root in differenced data "First difference" show that there is no unit root in all series and that all series are stationary.

Table 2. Test of Unit root in differenced data "First difference"

\begin{tabular}{|c|c|c|c|c|c|c|}
\hline & & \multirow[b]{2}{*}{$\begin{array}{c}\text { Test } \\
\text { Statistic }\end{array}$} & \multicolumn{3}{|c|}{ Interpolated Dickey-Fuller } & \multirow[b]{2}{*}{ MacKinnon approximation $p$-value for $Z(t)$} \\
\hline & & & $\begin{array}{c}1 \% \\
\text { Critical } \\
\text { value }\end{array}$ & $\begin{array}{c}5 \% \text { Critical } \\
\text { value }\end{array}$ & $\begin{array}{c}10 \% \\
\text { Critical } \\
\text { value }\end{array}$ & \\
\hline log_Sorghum (1st difference) & $\begin{array}{l}\text { Z(rho) } \\
\text { Z(t) }\end{array}$ & $\begin{array}{l}-68.21 \\
-7.556\end{array}$ & $\begin{array}{c}-19.476 \\
-3.535\end{array}$ & $\begin{array}{l}-13.556 \\
-2.904\end{array}$ & $\begin{array}{l}-10.892 \\
-2.587\end{array}$ & $0.000^{*}$ \\
\hline log_Maize (1st difference) & $\begin{array}{c}\text { Z(rho) } \\
\text { Z(t) }\end{array}$ & $\begin{array}{l}-46.52 \\
-6.917 \\
\end{array}$ & $\begin{array}{c}-19.476 \\
-3.535\end{array}$ & $\begin{array}{c}-13.556 \\
-2.904 \\
\end{array}$ & $\begin{array}{c}-10.892 \\
-2.587 \\
\end{array}$ & $0.000^{*}$ \\
\hline log_Rice (1st difference) & $\begin{array}{c}\text { Z(rho) } \\
\text { Z(t) }\end{array}$ & $\begin{array}{l}-41.75 \\
-5.309 \\
\end{array}$ & $\begin{array}{c}-19.476 \\
-3.535 \\
\end{array}$ & $\begin{array}{l}-13.556 \\
-2.904 \\
\end{array}$ & $\begin{array}{c}-10.892 \\
-2.587 \\
\end{array}$ & $0.000^{*}$ \\
\hline log_Wheat (1st difference) & $\begin{array}{c}\text { Z(rho) } \\
\mathrm{Z}(\mathrm{t}) \\
\end{array}$ & $\begin{array}{c}-62.176 \\
-8.823 \\
\end{array}$ & $\begin{array}{c}-19.476 \\
-3.535 \\
\end{array}$ & $\begin{array}{c}-13.556 \\
-2.904 \\
\end{array}$ & $\begin{array}{c}-10.892 \\
-2.587 \\
\end{array}$ & $0.000 *$ \\
\hline log_Irishipotato (1st difference) & $\begin{array}{c}\text { Z(rho) } \\
\text { Z(t) }\end{array}$ & $\begin{array}{l}-57.65 \\
-9.873 \\
\end{array}$ & $\begin{array}{c}-19.476 \\
-3.535 \\
\end{array}$ & $\begin{array}{c}-13.556 \\
-2.904 \\
\end{array}$ & $\begin{array}{c}-10.892 \\
-2.587 \\
\end{array}$ & $0.000 *$ \\
\hline log_Beans (1st difference) & $\begin{array}{c}\text { Z(rho) } \\
\text { Z(t) }\end{array}$ & $\begin{array}{c}-38.219 \\
-6.119 \\
\end{array}$ & $\begin{array}{c}-19.476 \\
-3.535\end{array}$ & $\begin{array}{l}-13.556 \\
-2.904 \\
\end{array}$ & $\begin{array}{c}-10.892 \\
-2.587 \\
\end{array}$ & $0.000^{*}$ \\
\hline
\end{tabular}

*, significant at $5 \%$

Table 3. Lag-order selection statistics (pre-estimation)

\begin{tabular}{|c|c|c|c|c|c|c|c|c|}
\hline lag & $\mathbf{L L}$ & LR & df & p & FPE & AIC & HQIC & SBIC \\
\hline 0 & 581.58 & 8.7E-15 & & & & -15.35 & $-15.27^{*}$ & $-15.16^{*}$ \\
\hline 1 & 629.63 & 96.10 & 36 & 0.000 & $6.3 e-15^{*}$ & $-15.67 *$ & -15.15 & -14.37 \\
\hline 2 & 657.59 & 55.93 & 36 & 0.018 & 8.0E-15 & -15.46 & -14.49 & -13.05 \\
\hline 3 & 686.87 & 58.56 & 36 & 0.010 & $1.0 \mathrm{E}-14$ & -15.28 & -13.87 & -11.75 \\
\hline 4 & 709.57 & 45.39 & 36 & 0.136 & $1.6 \mathrm{E}-14$ & -14.92 & -13.07 & -10.29 \\
\hline 5 & 743.61 & 68.08 & 36 & 0.001 & $1.9 \mathrm{E}-14$ & -14.87 & -12.57 & -9.12 \\
\hline 6 & 779.58 & 71.95 & 36 & 0.000 & $2.5 \mathrm{E}-14$ & -14.87 & -12.13 & -8.01 \\
\hline 7 & 814.69 & 70.22 & 36 & 0.001 & 3.7E-14 & -14.84 & -11.66 & -6.87 \\
\hline 8 & 857.37 & 85.35* & 36 & 0.000 & 5.6E-14 & -15.02 & -11.40 & -5.94 \\
\hline
\end{tabular}

Selection-order criteria: (Sample: 10/2007 - 12/2013); (Number of obs = 75)

\subsection{Test of Stability Condition and Determination of Optimum Lag-Order}

The VAR of differenced data satisfy stability condition because all the eigenvalues lie inside the unit circle. Therefore, this paper uses differenced data to determine the maximum lag which would be used to specify the optimum lag-order that should be used in VAR model to get estimates and forecasts. In this paper we found that at any lag less or equal to 8, VAR model for all differenced data satisfy stability condition while at any lag greater than 8, the VAR model of all differenced series does not satisfy stability condition (at least one eigenvalue lies outside the unit circle). Thus lag 8 was used to determine the optimum lag-order.
Table 3 shows the pre-estimation lag-order selection statistics using 8 as the maximum lag order to determine the appropriate VAR lag length. At 95\% confidence level, Likelihood Ratio (LR) test selected lag 8, Akaike information Criterion selected lag 1, Hannan-Quinn Information Criterion select lag 0 lag and Schwarz Bayesian Information Criterion selected lag 0 as the appropriate VAR lag length. This paper uses the optimum lag order "8”" selected under Likelihood Ration test.

\subsection{Vector Autoregression Results}

This paper uses a sample that took monthly prices of all specified food commodities from January 2007 to December 2013. The number of observation is 75; this does not include the first difference and the optimum lag- 
order of 8. Each equation was estimated with 49 parameters, the constant included. Table 4 shows that the RMSE for each equation is small, thus percentage changes in each independent variable should be well explained by percentage changes in independent variables recorded in previous months up to the 8 period before the current price. P-values show that all equations are statistically significant at $95 \%$ confidence level.

The $\mathrm{R}^{2}$ results show that: the current price of Sorghum can be explained by past prices of all food commodities specified in the model and its self by $63 \%$; the current price in Maize can be explained by past prices of all food commodities specified in the model and its self by $69 \%$; the current price of Rice can be explained by past prices of all food commodities specified in the model and its self by $68 \%$; the current price of Wheat should be explained by past prices of all specified food commodities in the model and its self by 66\%; the current price of Irish Potato should be explained by past prices of all specified food commodities and its self by $61 \%$; and the current price of Beans should be explained by past prices of all specified food commodities and its self by $71 \%$.

Table 4. VAR model fit

\begin{tabular}{|c|c|c|c|c|c|}
\hline Equation & Parms & RMSE & R-sq & chi2 & $\mathrm{P}>$ chi2 \\
\hline sorghum_1 & 49 & 0.080 & 0.6321 & 128.874 & 0.000 \\
\hline maize_- 1 & 49 & 0.088 & 0.6913 & 167.921 & 0.000 \\
\hline rice_t & 49 & 0.029 & 0.6858 & 163.694 & 0.000 \\
\hline irishpotato_1 & 49 & 0.124 & 0.6093 & 116.967 & 0.000 \\
\hline beans_1 & 49 & 0.087 & 0.7051 & 179.344 & 0.000 \\
\hline \multicolumn{2}{|c|}{ Sample: 10/2007 - 12/2013 } & & & No. of obs & 75 \\
\hline Log likelihood & 857.366 & & & AIC & -15.023 \\
\hline FPE & $5.58 \mathrm{E}-14$ & & & HQIC & -11.396 \\
\hline Det(Sigma_ml) & $4.74 \mathrm{E}-18$ & & & SBIC & -5.939 \\
\hline
\end{tabular}

\subsubsection{Granger Causality Test}

Granger test results show that: (i) changes in Maize, Rice, Wheat, Irish Potato, and Beans prices granger cause changes in Sorghum price; (ii) changes in Sorghum and Beans prices granger cause changes in Maize price; (iii) changes in Maize, Wheat, Irish Potato and Beans prices granger cause changes in Rice price; (iv) changes in Maize, Rice, Irish Potato, and Beans granger cause changes in Wheat; (v) changes in Sorghum, Rice, Beans prices granger cause change in Irish Potato price; and (vi) change in Sorghum, Rice, and Irish Potato granger cause changes in Beans price. The VAR model results show that:

The current price of Sorghum can significantly be explained by its own prices happened at the $3^{\text {rd }}, 4^{\text {th }}$ and $7^{\text {th }}$ periods prior to the current period, by Maize prices happened at the $2^{\text {nd }}, 3^{\text {rd }}, 6^{\text {th }}$ and $8^{\text {th }}$ periods prior to the current period, by Rice prices happened at the $3^{\text {rd }}$ and $7^{\text {th }}$ periods prior to the current period, by Wheat price happened at the $1^{\text {st }}$ period prior to the current period, by Irish Potato prices happened at the $1^{\text {st }}, 3^{\text {rd }}$, and $7^{\text {th }}$ periods prior to the current period, and by Beans prices happened at the $1^{\text {st }}, 2^{\text {nd }}, 4^{\text {th }}$, and $5^{\text {th }}$ periods prior to the current period.

The current price of Maize can significantly be explained by Sorghum prices happened at the $4^{\text {th }}$ and $6^{\text {th }}$ periods prior to the current period, by Rice price happened at the $1^{\text {st }}$ prior to the current period, by Wheat price happened at the $8^{\text {th }}$ period prior to the current period, and by Beans prices happened at the $1^{\text {st }}$, and the $6^{\text {th }}$ periods prior to the current period.

The current price of Rice can significantly be explained by its own prices happened at the $1^{\text {st }}, 3^{\text {rd }}$, and $8^{\text {th }}$ periods prior to the current period, by Sorghum price happened at the $7^{\text {th }}$ period prior to the current period, by Maize prices happened at the $2^{\text {nd }}$, and periods prior to the current period, by Wheat price happened at the $3^{\text {rd }}, 4^{\text {th }}$, and $7^{\text {th }}$ periods prior to the current period, by Irish Potato prices happened at the $2^{\text {nd }}, 6^{\text {th }}, 7^{\text {th }}$, and $8^{\text {th }}$ periods prior to the current period, and by Beans prices happened at the $2^{\text {nd }}, 4^{\text {th }}$, and $6^{\text {th }}$ periods prior to the current period.

The current price of Wheat can significantly be explained by its own prices happened at the $5^{\text {th }}$ and $8^{\text {th }}$ periods prior to the current period, by Maize prices happened at the $2^{\text {nd }}$ and $3^{\text {rd }}$ periods prior to the current period, by Rice prices happened at the $1^{\text {st }}, 7^{\text {th }}$, and $8^{\text {th }}$ periods prior to the current period, by Irish Potato prices happened at the $2^{\text {nd }}, 6^{\text {th }}$, and $7^{\text {th }}$ periods prior to the current period, and by Beans prices happened at the $2^{\text {nd }}$ and $5^{\text {th }}$ periods prior to the current period.

The current price of Irish Potato can significantly be explained by its own prices happened at the $6^{\text {th }}$ period prior to the current period, by Sorghum prices happened at the $2^{\text {nd }}, 3^{\text {rd }}, 5^{\text {th }}$, and $7^{\text {th }}$ periods prior to the current period, by Maize price happened at the $5^{\text {th }}$ periods prior to the current period, by Rice prices happened at the $2^{\text {nd }}$ and $7^{\text {th }}$ periods prior to the current period, by Wheat price happened at the $4^{\text {th }}$ and $7^{\text {th }}$ periods prior to the current period, and by Beans prices happened at the $2^{\text {nd }}, 5^{\text {th }}$ and $7^{\text {th }}$ periods prior to the current period.

The current price of Beans can significantly be explained by its own prices happened at the $6^{\text {th }}$ period prior to the current period, by Sorghum prices happened at the $4^{\text {th }}$ and $5^{\text {th }}$ periods prior to the current period, by Maize prices happened at the $2^{\text {nd }}, 3^{\text {rd }}$, and $6^{\text {th }}$ periods prior to the current period, by Rice price happened at the $8^{\text {th }}$ period prior to the current period, by Irish Potato prices happened at the $1^{\text {st }}$ and $8^{\text {th }}$ periods prior to the current period.

\subsubsection{Impulse Response Analysis}

Given the causality found in food prices series, this paper uses impulse response to show the effects of shock on the adjustment path of food prices and to assess how shocks to food prices of Sorghum, Maize, Rice, Wheat, Irish Potato, and Beans reverberate through a system.

The Table 5 shows that shock to Sorghum, Maize and Rice create smaller, but significant response and temporary oscillations in prices of Beans, Maize, Irish potato, Sorghum itself and Maize itself that does not die out quickly while on the other hand shocks to Sorghum and Maize prices create response to Rice and Wheat prices which dies out very quickly. Table 5 also shows that shock to Wheat, Irish Potato and Beans prices create smaller, but significant response and temporary oscillations in the price of Irish Potato itself, Beans itself, Sorghum, Maize, and Rice that does not die out quickly 
while on the other hand shocks to Wheat, Irish Potato, and Beans prices create response to Rice and Wheat which dies out very quickly.

Before forecasting food prices volatility (See annex II) from January to December 2014, the analysis of impulse responses helped us to understand the behavior of the price of one food commodity resulting from a shock in the price of other food commodity. As the series used in the
VAR model were stationary, we generally observed that shock to the price of one food commodity creates smaller, but significant response and temporary oscillations in other food commodities and itself but the impact of shock in one food commodity's price on the price of other food commodity cannot be persistent and that their effects eventually die out.

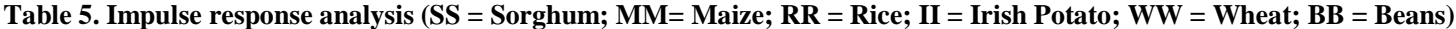

\begin{tabular}{|c|c|c|c|c|c|c|c|c|c|}
\hline & $\mathrm{i}=\mathrm{SS} \_r=\mathrm{SS}$ & $\mathrm{i}=\mathrm{SS} \_r=\mathrm{MM}$ & $\mathrm{i}=\mathrm{SS} \_r=\mathrm{RR}$ & $i=S S \_r=W W$ & $\mathrm{i}=\mathrm{SS} \_r=\mathrm{II}$ & $\mathbf{i}=\mathbf{S S} \_r=\mathbf{B B}$ & $\mathbf{i}=\mathbf{M M} \mathbf{r}=\mathrm{SS}$ & $\mathbf{i}=\mathbf{M} \_r=\mathbf{M}$ & $\mathrm{i}=\mathrm{MM}$ _r=RR \\
\hline 0 & 0.0474 & 0.0285 & 0.0059 & 0.0024 & -0.0101 & 0.0109 & 0.0000 & 0.0430 & 0.0081 \\
\hline 1 & 0.0021 & 0.0079 & 0.0057 & 0.0036 & -0.0049 & -0.0029 & 0.0025 & 0.0096 & 0.0048 \\
\hline 2 & -0.0039 & 0.0060 & 0.0032 & 0.0073 & -0.0247 & -0.0170 & 0.0021 & -0.0014 & 0.0035 \\
\hline 3 & 0.0138 & -0.0030 & 0.0049 & -0.0012 & -0.0084 & -0.0099 & 0.0026 & -0.0008 & 0.0050 \\
\hline 4 & 0.0065 & -0.0240 & 0.0032 & -0.0053 & 0.0286 & -0.0083 & 0.0081 & 0.0036 & 0.0053 \\
\hline 5 & 0.0023 & 0.0040 & 0.0032 & 0.0036 & 0.0184 & -0.0053 & 0.0160 & 0.0054 & 0.0054 \\
\hline 6 & 0.0180 & 0.0142 & 0.0060 & 0.0004 & -0.0007 & 0.0025 & 0.0059 & -0.0007 & 0.0035 \\
\hline 7 & 0.0020 & -0.0139 & 0.0045 & 0.0030 & -0.0171 & 0.0088 & 0.0021 & 0.0002 & 0.0026 \\
\hline 8 & -0.0052 & 0.0099 & 0.0036 & -0.0020 & -0.0023 & -0.0186 & -0.0030 & -0.0038 & -0.0003 \\
\hline 9 & 0.0048 & 0.0014 & -0.0010 & 0.0005 & 0.0070 & -0.0127 & -0.0012 & -0.0159 & -0.0053 \\
\hline 10 & -0.0055 & -0.0114 & -0.0058 & 0.0007 & 0.0110 & 0.0079 & 0.0069 & -0.0076 & -0.0017 \\
\hline 11 & -0.0011 & 0.0041 & -0.0029 & 0.0008 & 0.0028 & -0.0039 & 0.0007 & 0.0041 & -0.0018 \\
\hline \multirow[t]{2}{*}{12} & 0.0173 & 0.0069 & 0.0008 & -0.0054 & -0.0015 & 0.0052 & -0.0018 & 0.0016 & -0.0011 \\
\hline & $\mathbf{i}=\mathbf{M M} \mathbf{r}=\mathbf{W W}$ & $\mathbf{i}=\mathbf{M M} \mathbf{r}=\mathbf{I I}$ & $\mathbf{i}=\mathbf{M M} \mathbf{}=\mathbf{B B}$ & $\mathbf{i}=\mathbf{R R} \_r=S S$ & $\mathrm{i}=\mathrm{RR}$ _r=MM & $\mathbf{i}=\mathbf{R} \_\mathbf{r}=\mathbf{R}$ & $\mathbf{i}=\mathbf{R R \_ r}=\mathbf{W W}$ & $\mathrm{i}=\mathrm{RR}$ r $=$ II & i=RR_r=BB \\
\hline 0 & 0.0035 & -0.0094 & 0.0126 & 0.00000 & 0.00000 & 0.01347 & 0.00323 & 0.03896 & 0.00701 \\
\hline 1 & 0.0058 & 0.0029 & -0.0118 & 0.00522 & 0.01400 & 0.00247 & 0.01055 & -0.01750 & 0.01012 \\
\hline 2 & 0.0003 & 0.0123 & -0.0092 & -0.00514 & 0.01470 & 0.00200 & 0.00678 & 0.01311 & 0.00144 \\
\hline 3 & -0.0044 & 0.0038 & 0.0039 & -0.00404 & -0.00728 & -0.00269 & -0.00175 & 0.00219 & 0.01068 \\
\hline 4 & 0.0024 & 0.0008 & 0.0112 & 0.00256 & -0.00132 & 0.00047 & -0.00649 & -0.01792 & -0.00064 \\
\hline 5 & 0.0009 & 0.0066 & 0.0072 & -0.00423 & 0.00015 & -0.00126 & 0.00056 & -0.00203 & -0.00358 \\
\hline 6 & 0.0070 & -0.0003 & -0.0095 & -0.00086 & 0.00241 & -0.00094 & -0.00199 & 0.00273 & -0.00711 \\
\hline 7 & 0.0014 & -0.0054 & -0.0038 & 0.00128 & 0.00087 & -0.00192 & 0.00137 & 0.01307 & -0.00166 \\
\hline 8 & 0.0063 & 0.0001 & -0.0074 & 0.00403 & -0.00438 & -0.00311 & -0.00057 & -0.00514 & -0.00384 \\
\hline 9 & -0.0027 & 0.0138 & -0.0050 & -0.00467 & -0.00887 & 0.00204 & -0.00152 & 0.00162 & -0.00853 \\
\hline 10 & -0.0069 & 0.0034 & -0.0023 & 0.00279 & -0.00607 & 0.00018 & 0.00033 & 0.00140 & 0.00590 \\
\hline 11 & 0.0000 & -0.0005 & -0.0048 & 0.00794 & 0.00023 & 0.00042 & -0.00131 & 0.00225 & 0.00220 \\
\hline \multirow[t]{2}{*}{12} & 0.0041 & -0.0103 & -0.0035 & -0.00260 & 0.00694 & -0.00013 & 0.00473 & 0.00399 & -0.00155 \\
\hline & $\mathbf{i}=\mathbf{W W} \_r=S S$ & $\mathbf{i}=\mathbf{W} \_r=M$ & $\mathrm{i}=\mathrm{WW}$ _r=RR & $\mathbf{i}=\mathbf{W} \_r=W$ & WW_r=II & WW_r=BB & $\mathrm{i}=\mathrm{II} \_r=\mathrm{SS}$ & I_r=MM & i=II_r=RR \\
\hline 0 & 0.00000 & 0.00000 & 0.00000 & 0.02954 & 0.00493 & -0.00133 & 0.00000 & .00000 & 0.00000 \\
\hline 1 & -0.01643 & -0.00182 & -0.00153 & -0.00141 & 0.00845 & -0.00318 & 0.01778 & .00541 & -0.00272 \\
\hline 2 & -0.00479 & 0.00390 & 0.00104 & -0.00175 & 0.00372 & 0.01223 & 0.00405 & .01615 & 0.00246 \\
\hline 3 & 0.00326 & -0.00222 & -0.00169 & -0.00300 & 0.01776 & 0.00728 & 0.00743 & .00273 & 0.00238 \\
\hline 4 & 0.00137 & -0.00492 & 0.00259 & -0.00340 & -0.00916 & 0.00003 & 0.00196 & .00176 & -0.00153 \\
\hline 5 & -0.00572 & 0.01839 & -0.00032 & -0.00127 & -0.00730 & 0.00928 & -0.00858 & .00371 & -0.00361 \\
\hline 6 & 0.00103 & 0.00623 & 0.00023 & 0.00485 & -0.00586 & 0.00152 & 0.00189 & 0.01120 & -0.00154 \\
\hline 7 & -0.00563 & -0.00029 & -0.00055 & 0.00395 & 0.00299 & -0.00224 & -0.00864 & .00942 & -0.00072 \\
\hline 8 & -0.00080 & -0.00991 & -0.00139 & -0.00792 & 0.00252 & -0.00682 & -0.00982 & .00583 & -0.00213 \\
\hline 9 & 0.00228 & -0.00124 & -0.00149 & 0.00196 & 0.00331 & 0.00709 & 0.00167 & .01411 & 0.00386 \\
\hline 10 & -0.00426 & -0.00189 & -0.00142 & 0.00042 & -0.00066 & 0.00507 & -0.00192 & 0.00155 & 0.00043 \\
\hline 11 & 0.00506 & -0.00211 & 0.00011 & -0.00267 & -0.00629 & -0.00061 & -0.00238 & .00382 & -0.00009 \\
\hline \multirow[t]{2}{*}{12} & 0.00441 & 0.00319 & 0.00157 & -0.00293 & 0.00120 & -0.00741 & 0.00124 & .01248 & 0.00214 \\
\hline & $\mathbf{i}=\mathbf{I I} \_r=W W$ & i=II_i=II & i=II_r=BB & $\mathrm{i}=\mathbf{B B} \_r=S S$ & $\mathbf{i}=\mathbf{B B} \_r=M M$ & $\mathrm{i}=\mathrm{BB} \_r=\mathrm{RR}$ & $\mathbf{i}=\mathbf{B B} \_r=W W$ & $\mathrm{i}=$ BB_r=II & $\mathrm{i}=\mathbf{B B} \_r=\mathbf{B B}$ \\
\hline 0 & 0.00000 & 0.06008 & 0.01686 & 0.00000 & 0.00000 & 0.0000 & 0.00000 & 0.00000 & 0.04469 \\
\hline 1 & 0.00046 & -0.00943 & 0.02295 & 0.00889 & 0.02049 & 0.0008 & -0.00369 & -0.01019 & -0.00818 \\
\hline 2 & 0.00529 & -0.01783 & 0.0005 & -0.01324 & 0.00389 & -0.0046 & 0.0094 & -0.0091 & -0.0078 \\
\hline 3 & 0.00185 & -0.00629 & -0.00788 & -0.00751 & -0.00862 & -0.00166 & -0.00302 & 0.00312 & -0.004 \\
\hline 4 & 0.00194 & -0.02032 & -0.00874 & 0.00063 & -0.00563 & -0.00113 & -0.00828 & -0.00122 & -0.00475 \\
\hline 5 & -0.00151 & -0.0012 & -0.01583 & 0.01211 & -0.00008 & 0.00342 & -0.0092 & 0.00823 & -0.00189 \\
\hline 6 & -0.00263 & -0.00568 & -0.01249 & -0.00482 & -0.00843 & 0.00173 & 0.0067 & -0.00193 & -0.00822 \\
\hline 7 & 0.00173 & 0.00883 & -0.00463 & 0.00301 & 0.0087 & 0.00324 & 0.00052 & -0.0133 & 0.00044 \\
\hline 8 & -0.00056 & -0.00027 & 0.00675 & -0.00513 & -0.00249 & 0.00088 & 0.00223 & -0.00992 & -0.00196 \\
\hline 9 & -0.00982 & 0.01006 & 0.00155 & -0.01089 & -0.00717 & -0.00066 & 0.0027 & 0.02444 & -0.00533 \\
\hline 10 & 0.00399 & 0.01228 & 0.00576 & 0.00134 & -0.00697 & -0.00068 & -0.00074 & 0.00675 & 0.00703 \\
\hline 11 & 0.00269 & -0.00206 & 0.00589 & 0.00089 & 0.00719 & -0.00195 & -0.00266 & 0.00432 & 0.01507 \\
\hline 12 & -0.00315 & -0.00347 & 0.00901 & -0.00053 & 0.00511 & -0.00068 & 0.00183 & 0.00127 & 0.01149 \\
\hline
\end{tabular}

\section{Conclusion}

This paper used VAR model to test stationary in food prices series, to check on stability condition in transformed series, to test granger causality among food prices volatility, to analyze impulse response of shock in the price of one food commodity to other food commodities in the model, and to forecast food prices volatility in Rwanda. The major findings of this study showed that the first difference of logged price series is stationary and satisfy stability condition. The granger causality test showed that there exists food prices granger causality in the selected food commodities. Thus the impulse response analysis showed that shock to the price of one food commodity create smaller, but significant response and temporary oscillations in other food commodities and itself but which impact on other food 
process do not persistent and that their effects eventually die out. However, this paper showed that forecasted food price in one commodity can be gradually attributed to the past price volatility of the same commodity and that of others.

This paper found that the literature on the analysis of food price volatility in Rwanda is scarce and this study attempted to cover this gap. Therefore, the used model contains two policy parameters that are outside the control of policymakers in regards with the link that exist between food price volatility and food price stability. These policy parameters are food price volatility forecasts and food price volatility causal analysis. Food price volatility forecasts would help to assess future variations in food price commodities. Granger causality should help policymakers to find out which food commodities' price volatility granger cause price volatility in the other food commodities and to identify how price policies should be formulated when trying to stabilize food price volatility. Basing on empirical results policymaker should be informed on how instable food prices are and at which magnitude price volatility in one commodity should lead to price volatility in the other food commodity. However, this study found that food commodities which price volatility granger cause price volatility in other food commodities have pooling and pushing effects on the prices of those other food commodities.

\section{Acknowledgement}

The author wishes to acknowledge technical assistance generously given by Mr. Enock Chinganda Senior Expert in Statistics.

\section{References}

[1] Alderman, H. (1992), Incomes and Food Security in Ghana. Cornell Food and Nutrition policy program. Washington, DC.

[2] Bernhard Troester (2012) The determinants of the recent food price surges: A basic supply and demand model. Working Paper. University of Applied Sciences. Hochschule für Technik und Wirtschaft Berlin (HTW).

[3] Bruce E. Hansen (2013) Econometrics. University of Wisconsin.

\section{Annexes}

\section{Annex I: Granger Causality Test}

\begin{tabular}{|ccccc|}
\hline Equation & Excluded & chi2 & df & Pro> chi2 \\
\hline Sorghum & Maize & 21.35 & 8 & $0.006^{*}$ \\
& Rice & 15.11 & 8 & $0.057^{* *}$ \\
& Wheat & 13.64 & 8 & $0.092^{* *}$ \\
& Irishpotato & 24.36 & 8 & $0.002^{*}$ \\
& Beans & 24.09 & 8 & $0.002^{*}$ \\
& All & 113.64 & 40 & $0.000^{*}$ \\
\hline Maize & Sorghum & 19.67 & 8 & $0.012^{*}$ \\
& Rice & 10.15 & 8 & 0.255 \\
& Wheat & 10.79 & 8 & 0.214 \\
& Irishpotato & 7.37 & 8 & 0.498 \\
& Beans & 29.02 & 8 & $0.000^{*}$ \\
& All & 131.40 & 40 & $0.000^{*}$ \\
\hline Rice & Sorghum & 8.03 & 8 & 0.431 \\
& Maize & 19.12 & 8 & $0.014^{*}$ \\
& Wheat & 23.48 & 8 & $0.003^{*}$ \\
& Irishpotato & 26.68 & 8 & $0.001^{*}$ \\
& Beans & 26.77 & 8 & $0.001^{*}$ \\
& All & 96.18 & 40 & $0.000^{*}$ \\
\hline$*$ **, significant at 5\% and 10\% respectively & & \\
& & &
\end{tabular}

[4] Bryce Cooke and Miguel Robles (2009). Recent Food Prices Movements: A time Series Analysis. IFPRI Discussion Paper No. 000942.

[5] Chris Brooks (2008) Introductory Econometrics for Finance. $2^{\text {nd }}$ Edition. Cambridge University Press.

[6] Hanawa Peterson and William G. Tomek (2000) Implication od Deflating Commodity Prices for Time Series Analysis. Paper. Chicago.

[7] ISSER, Institute of Statistic, Social and Economic Research (2008). State of the Ghanaian Economy University of Ghanalegon.

[8] John K. M. Kuwornu (2011) Analysis of Foodstuff Price Volatility in Ghana: Implications for Food Security. European Journal of Business and Management. ISSN 2222-1905 (Paper) ISSN 22222839 (Online) Vol. 3, No. 4, 2011.

[9] Lovendal, C. R., Jakobsen, K. T., and Jacque, A. (2007). Food Prices and Food Security in Trinidad and Tobago. Agricultural Development Economics Division. Food and Agricultural Organization. ESA Working paper No. 07-27.

[10] M. Bruna Zolin and Bernadette Andreosso-O’Callaghan (2010) Long-term cereal price changes: how important is the speculative element1. Working Paper s. Department of Economics. Ca' Foscari University of Venice.

[11] MINAGRI, NISR, et al (2009) Comprehensive Food Security and Vulnerability Analysis and Nutrition Survey. Government of Rwanda.

[12] MINAGRI, NISR, et al (2011) Enquête Intégrale sur les Conditions de Vie des Ménages. Government of Rwanda.

[13] MINAGRI, NISRR, et al (2012) Comprehensive Food Security and Vulnerability Analysis and Nutrition Survey. Government of Rwanda.

[14] NISR, National Institute of Statistics of Rwanda (2011) GDPNational Accounts. Government of Rwanda.

[15] NISR, National Institute of Statistics of Rwanda, et al (2012) 2012 Population and Housing Census. Provision Results. Government of Rwanda.

[16] Parry, M. Rosenzweig, C. and Livermor, M. (2005), Climate Change, Global Food supply and Risk of Hunger. Philosophical Transactions of the Royal Society B. 360 (1463) 2125-2138.

[17] Philip Kostov and John Lingard () Seasonally specific model analysis of UK cereals prices. United Kingdom

[18] Shahidur Rashid (2011) Intercommodity Price Transmission and Food Price Policies: An Analysis of Ethiopian Cereal Markets. Working Paper 22.

[19] Shively, G. E. (1996). Food Price variability and Economic Reform: An ARCH Approach for Ghana. American Journal of Agricultural Economics, 78 (1) 126-136.

[20] Sinha, R. (1976), Food and Poverty. Croom Helm London. 1976.

[21] Willard G. Manning and John Mullahy (2001) Estimating log models: to transform or not to transform? Journal of Health Economics 20 (2001) 461-494.

[22] Xiangyu Tang, Chunyu Yang, Jie Zhou (2009) Stock Price Forecasting by Combining News Mining and Time Series Analysis.

\begin{tabular}{|ccccc|}
\hline Equation & Excluded & chi2 & df & Pro> chi2 \\
\hline Wheat & Sorghum & 5.48 & 8 & 0.705 \\
& Maize & 14.37 & 8 & $0.073^{* *}$ \\
& Rice & 20.39 & 8 & $0.009^{*}$ \\
& Irishpotato & 27.41 & 8 & $0.001^{*}$ \\
& Beans & 17.78 & 8 & $0.023^{*}$ \\
& All & 114.40 & 40 & $0.000^{* *}$ \\
\hline Irishpotato & Sorghum & 33.41 & 8 & $0.000^{* *}$ \\
& Maize & 7.24 & 8 & 0.511 \\
& Rice & 15.72 & 8 & $0.047^{*}$ \\
& Wheat & 11.96 & 8 & 0.153 \\
& Beans & 15.56 & 8 & $0.049^{*}$ \\
& All & 92.48 & 40 & $0.000^{* *}$ \\
\hline Beans & Sorghum & 16.22 & 8 & $0.039^{*}$ \\
& Maize & 11.71 & 8 & 0.165 \\
& Rice & 17.86 & 8 & $0.022^{*}$ \\
& Wheat & 10.32 & 8 & 0.243 \\
& Irishpotato & 31.33 & 8 & $0.000^{*}$ \\
& All & 111.00 & 40 & $0.000^{*}$ \\
\hline
\end{tabular}


Annex II: Food Price Volatility Forecasts: January to December 2014

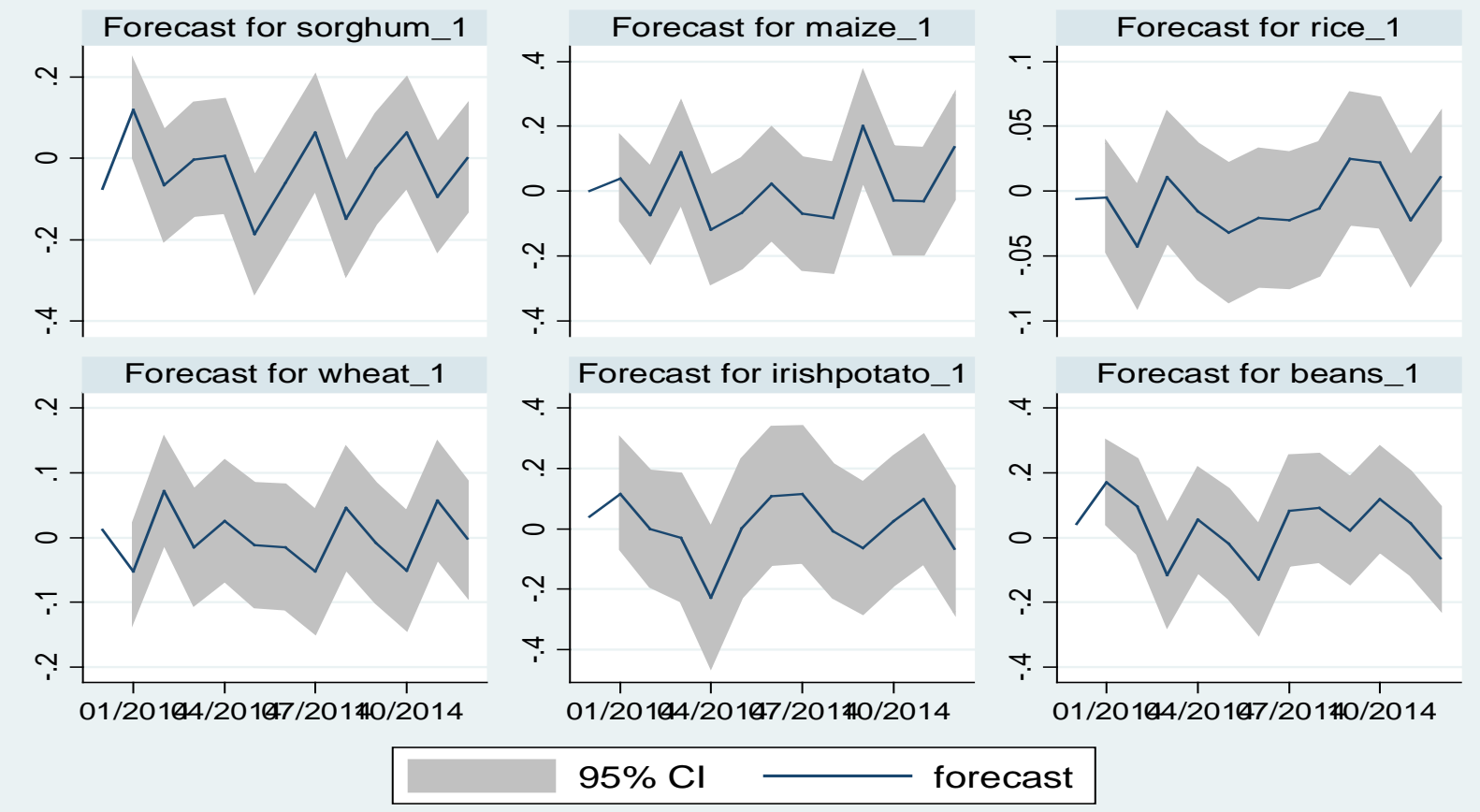

